\title{
Assessment of threat arising by closed - volume explosions of fuel - air mixtures
}

\author{
Andrzej PAPLIŃSKI*1 \\ ${ }^{1}$ Faculty of Mechatronics, Armament and Aerospace, Military University of Technology, Warsaw, Poland
}

\begin{abstract}
The method of estimation of maximal parameters of combustion of gaseous mixtures in closed space is presented. Estimation of chemical composition of combustion products is based on simplified rules of decomposition of reactive medium. Exemplary calculations of temperature, pressure, heat of combustion of hydrocarbon/air mixtures are presented. The accuracy of presented method was validated by comparison with calculations performed by thermodynamic numerical code that include wide list of chemical substances present in combustion products. The obtained results confirm applicability of the proposed method to predict closed space combustion parameters of gaseous mixtures. Semi-empirical methods of estimation of flammability limits are briefly referred.
\end{abstract}

Keywords: fuel-air mixtures, closed space combustion, decomposition rules.

\section{Introduction}

In any use of combustible material in liquid or gaseous phase the threat arises of uncontrolled formation and combustion of fuel-air mixtures. Hydrocarbon fuels constitute a wide class of substances that may form combustible gas or vapor mixtures with air. The global consumption of natural gas has doubled from 1980 to 2010 and is still growing, exceeds of 3500 billion of cubic meters per year [9].

The widespread employment of gaseous fuels raises demand of straight and effective methods that would enable satisfactory prediction of combustion and explosion parameters with account of current concentration of gas or vapor in fuel/air cloud.

Two main geometrical configurations can be discerned that influence on mechanisms of combustion of fuel/air mixtures, combustion in open atmosphere and transformation in closed or partly constrained spaces. Combustion of free air gaseous mixtures proceeds at moderate velocities. Experimentally observed flame velocity of combustion of fuel/air clouds of typical hydrocarbons (methane, propane, etc.) rarely exceeds of $10 \mathrm{~m} / \mathrm{s}$. The flame velocities measured in unconfined conditions were of $5,8 \mathrm{~m} / \mathrm{s}$ for methane and $6,1 \mathrm{~m} / \mathrm{s}$ for propane at distances of about of 10 meters from the ignition point [1]. The observed free air flame velocities are higher than laminar burning velocity estimated in laboratory conditions. Laminar burning velocity is quoted as equal of $45 \mathrm{~cm} / \mathrm{s}$ for methane while $39 \mathrm{~m} / \mathrm{s}$ for propane [17]. Acceleration of free air spherical flame occurs due to instabilities that are caused by random fluctuations of the flow induced by expansion of combustion products [1].

The arising turbulence speeds up the combustion. The role of turbulence increases by combustion in spaces of irregular geometry, with protrusive elements, coarse walls etc. In long channels equipped with obstacles, wires or/and other elements inducing instabilities combustion front may to outscore sound velocity and formation of detonation wave may occur. The extensive review and analysis of unsteady dynamics of flame in ducts was performed by Ciccareli and Dorofieev [7]. Run-up distances to detonation onset together with the role of instabilities and flame stretch phenomena are assessed. Presented results can be of purpose by analysis of possible detonation hazard in long corridors, lift shafts etc.

By combustion in closed rooms, compartments the pressure waves which move with sound velocity cannot take off and dispel combustion energy as it proceeds by combustion in open air. Elemental pressure wavelets reflect from

*Corresponding author: E-mail address: andrzej.paplinski@wat.edu.pl (Andrzej PAPLIŃSKI)

https://dx.doi.org/10.37105/iboa.114

Received 21 September 2021

Available online 15 December 2021

ISSN 2450-1859, eISSN 2450-8721

Published by Centrum Rzeczoznawstwa Budowlanego 
surrounding walls and accumulate to increase pressure and temperature in the reacting vessel. Then, after relatively slow start, combustion speeds up and maximal combustion parameters are attained [1].

Two characteristic parameters are usually discerned to characterize the pressure course during combustion of gaseous mixtures in closed spaces. They are maximal rate of pressure rise $(\mathrm{d} p / \mathrm{d} t)_{\max }$ and maximum vessel pressure $p_{\max }$. The value of maximal rate of pressure rise is related to volume of combustion space by the relation $[1,22]$.

$$
K_{s t}=\left(\frac{d p}{d t}\right)_{\max } \cdot V^{1 / 3}
$$

where $K_{s t}$ is a constant characterizing the combustible mixture and $V$ is the vessel volume.

Values of deflagration index $K_{s t}$ for several gases are quoted in [22]. Maximal combustion pressure that is attained by combustion in closed space is an important factor that characterizes damage potential of the process.

In view of distinctive vivacity, the combustion process in closed space in most cases turns out into explosion. Then, uncontrolled closed space combustion is usually considered as the explosive-type threat which mitigation may be acquired by introduction of well-timed venting [6].

In the paper a method of prediction of maximal combustion parameters attained by combustion of gaseous mixtures in closed spaces is presented. The obtained quantities correspond to explosion parameters. The method is illustrated by exemplary evaluations carried out for gaseous hydrocarbons mixtures with air. Molar compositions, combustion heats, temperatures, pressures at various concentrations of fuel are estimated. Chemical composition of combustion products is estimated upon simplified rules.

The presented approach may be applied also for calculation of explosion parameters of air suspensions that may be formed by release of liquid hydrocarbons [4]. Estimation of pressure and temperature loads is a crucial task by assuring of safe exploitation of buildings and housings $[2,3]$.

\section{Simplified methods of estimation of chemical composition of combus- tion products}

Employment of simplified methods for estimation of combustion products composition dates to Mallard and Le Chatelier [19]. Upon anticipated composition of combustion products, they used average heat capacities for evaluation of combustion temperature. Thereby the thesis of full carbon gasification by combustion of gaseous mixtures was formulated.

Simplified rules of prediction of chemical composition of explosion products are often used as the first-choice method in estimation of detonation parameters of condensed explosive charges [16, 20]. The important difficulty results from non-ideal behavior of gases and condensed phase substances at high temperatures and pressures. Then, upon assumed chemical composition of products the explosion energy is calculated only. Other parameters as detonation velocity and pressure are calculated from semi-empirical formulae. One of well-known is the method of Kamlet and Jacobs designed for CHNO explosives [14]. In further approaches energetic materials of more complex elemental composition are considered [15].

The main purpose of the present work was to deliver a relatively simple approach that will enable estimation of complete parameters of closed volume combustion. In comparison to calculation of condensed explosives both temperature and pressure are estimated. The method is indented to be a straight calculation procedure that may be implemented into calculating devices being in everyday use.

\subsection{Mixtures with positive oxygen balance}

Estimation of chemical composition of combustion products of mixtures with positive oxygen balance is based on the principle of formation of substances in maximal oxidation degree. The overall reaction of CHNO mixture is written as

$$
\mathrm{C}_{a} \mathrm{H}_{b} \mathrm{O}_{c} \mathrm{~N}_{d} \Rightarrow a \mathrm{CO}_{2}+\frac{b}{2} \mathrm{H}_{2} \mathrm{O}+\frac{d}{2} \mathrm{~N}_{2}+y_{\mathrm{O} 2} \mathrm{O}_{2}
$$


where

$$
y_{O 2}=0.5\left(c-2 a-\frac{b}{2}\right)
$$

The assumed decomposition path (2) coincides with the Berthelot maximal heat liberation rule. Berthelot approach may be applied also for explosives of negative oxygen balance [14].

\subsection{Mixtures with moderately negative oxygen balance}

By estimation of chemical composition of combustion products of mixtures of moderate negative balance, the principle of full oxidation of carbon is assumed. The decomposition path is then to be

$$
C_{a} H_{b} O_{c} N_{d} \Rightarrow\left(c-a-\frac{b}{2}\right) C_{2}+\left(2 a-c+\frac{b}{2}\right) C O+\frac{b}{2} H_{2} O+\frac{d}{2} N_{2}
$$

The limiting condition is $\mathrm{CO}_{2}$ formation that may occur when $\mathrm{c}-\mathrm{a}-\mathrm{b} / 2>0$. Therefore, the formula (4) may be applied if

$$
c \geq a+\frac{b}{2}
$$

\subsection{Mixtures with significantly negative oxygen balance}

In mixtures with $c<a+b / 2$ some portion of unreacted fuel is to remain in combustion products. In contrary to rules adopted for estimation of explosion and detonation products of condensed explosive charges [16, 20] in the presented method no formation of elemental carbon (graphite) $\mathrm{C}_{(s)}$ is considered

$$
C_{a} H_{b} O_{c} N_{d} \Rightarrow a C O_{2}+(c-a) H_{2} O+\left(a+\frac{b}{2}-c\right) H_{2}+\frac{d}{2} N_{2}
$$

Graphite formation that takes place by explosion of condensed explosives is caused by restrained volume accessible for explosion products. The conditions of minimization of number of moles in gaseous phase lead to creation of elemental carbon $\mathrm{C}_{(s)}($ soot $)$.

\section{Estimation of combustion parameters}

\subsection{Estimation of combustion energy}

The energy $Q_{v}$ liberated in combustion is estimated from Hess's Law

$$
Q_{v}=y_{C O 2} \cdot Q_{C O 2}^{t w}+y_{C O} \cdot Q_{C O}^{t w}+y_{H 2 O} \cdot Q_{H 2 O}^{t w}-Q_{C_{a} H_{b} O_{c} N_{d}}^{t w}
$$

where $y_{i}$ are molar numbers and $Q_{i}^{t w}, Q_{C_{a} H_{b} O_{c} N_{d}}^{t w}$ are the heats of formation of combustion products and initial reactive material, respectively. The standard heat of formation is the energy of a substance referred to its elements in their standard states ( $\mathrm{Ar}, \mathrm{Ne}, \mathrm{O}_{2}, \mathrm{~N} 2, \mathrm{H}_{2}, \mathrm{C}_{(s)}, \mathrm{Al}_{(s)}, \mathrm{S}_{(s)}$ etc.). Then, heats of formation of the elements in their standard states are equal zero.

However, in most thermodynamic tables $[5,10]$ rather enthalpies of formation $\left(\Delta_{f} H\right)$ are quoted instead of heats of formation. In Tables 1 and 2 enthalpies of formation $\left(\Delta_{f} H\right)$ as well as evaluated heats of formation of main combustion products and typical gaseous hydrocarbons are quoted.

Heats of formation differs from enthalpies of formation in work performed by volume alteration that occurs by formation of the considered chemical substance from elements in standard state at constant pressure

$$
\Delta_{f} H=-\left(Q^{t w}+\Delta W\right)
$$


Table 1. Enthalpy of formation and heats of formation of main combustion products [5]

\begin{tabular}{|c|c|c|}
\hline \multirow{2}{*}{ Compound } & $\Delta_{f} H(298.15 K)$ & $\mathrm{Q}^{t w}(298.15 \mathrm{~K})$ \\
\cline { 2 - 3 } & $\mathrm{kJ} / \mathrm{mol}$ & $\mathrm{kJ} / \mathrm{mol}$ \\
\hline $\mathrm{CO} 2$ & -241.814 & 393.510 \\
\hline $\mathrm{CO}$ & -110.530 & 111.780 \\
\hline $\mathrm{H} 2 \mathrm{O}$ & -393.510 & 240.580 \\
\hline
\end{tabular}

Table 2. Enthalpy of formation and heats of formation of gaseous hydrocarbons [23]

\begin{tabular}{|c|c|c|c|}
\hline \multicolumn{2}{|c|}{ Compound } & $\Delta_{f} H(298.15 K)$ & $\mathrm{Q}^{t w}(298.15 \mathrm{~K})$ \\
\cline { 3 - 4 } & $\mathrm{kJ} / \mathrm{mol}$ & $\mathrm{kJ} / \mathrm{mol}$ \\
\hline $\mathrm{CH}_{4}$ & methane & -74.60 & 72.12 \\
\hline $\mathrm{C}_{2} \mathrm{H}_{6}$ & ethane & -84.00 & 79.04 \\
\hline $\mathrm{C}_{3} \mathrm{H}_{8}$ & propane & -104.70 & 97.24 \\
\hline $\mathrm{C}_{4} \mathrm{H}_{10}$ & butane & -125.60 & 115.73 \\
\hline $\mathrm{C}_{5} \mathrm{H}_{12(g)}$ & pentane & -146.50 & 134.10 \\
\hline $\mathrm{C}_{6} \mathrm{H}_{14(g)}$ & hexane & -167.20 & 152.32 \\
\hline $\mathrm{C}_{7} \mathrm{H}_{16(g)}$ & heptane & -187.80 & 170.44 \\
\hline $\mathrm{C}_{8} \mathrm{H}_{18(g)}$ & octane & -208.50 & 188.66 \\
\hline $\mathrm{C}_{2} \mathrm{H}_{4}$ & ethylene & 52.40 & -54.88 \\
\hline $\mathrm{C}_{3} \mathrm{H}_{6}$ & propylene & 20.00 & -25.36 \\
\hline $\mathrm{C}_{4} \mathrm{H}_{8}$ & butene & 6.99 & -0.450 \\
\hline $\mathrm{C}_{3} \mathrm{H}_{6}$ & cyclopropane & 52.00 & -56.86 \\
\hline $\mathrm{C}_{6} \mathrm{H}_{6(g)}$ & benzene & 82.90 & -87.86 \\
\hline $\mathrm{C}_{2} \mathrm{H}_{4} \mathrm{O}_{(g)}$ & ethylene oxide & -51.00 & 47.20 \\
\hline
\end{tabular}

where

$$
\Delta W=-p^{0} \cdot \Delta V=-p^{0} \cdot\left(V-\sum_{i} V_{s t n d}^{i}\right)
$$

$V$ - molar volume of the formed substance, $V_{\text {stnd }}^{i}$ - volumes of contributing elements "i" in standard state, $p^{0}$ is the pressure at which the formation process occurs. It should be noted that in many practical applications replacing of heat of formation by enthalpy formation is acceptable i.e., $Q^{t w}=-\Delta_{f} H$ [16], for the reason of simplicity.

\subsection{Pressure and temperature evaluation}

Evaluation of pressure succeeds after estimation of combustion temperature. For a given value of combustion temperature $T$

$$
p \cdot V=\sum_{i} y_{i} \cdot R \cdot T
$$


where $y_{i}$ are the molar numbers of products in gaseous chase, $V$ - vessel volume and the gas constant $\mathrm{R}=8,31447$ $\mathrm{J} / \mathrm{molK}$.

Combustion temperature $T$ is determined by matching the integral of heat capacities to be equal to combustion heat $\mathrm{Q}_{v}$

$$
Q_{v}=\int_{T_{0}}^{T} \sum_{i} y_{i} \cdot C_{v i}(T) \cdot d T
$$

where $C_{v i}$ are the constant volume molar heat capacities and $T_{0}$ is the initial temperature of the mixture. The integral may be replaced by introduction of average heat capacities $\hat{C}_{v i}$.

$$
\hat{C}_{v}=\frac{\int_{T_{0}}^{T} C_{v}(T) \cdot d T}{T}
$$
3

The temperature dependence of mean molar heat capacities of the main combustion products is presented in Table

Table 3. Average molar heat capacities at constant volume, evaluated after [10]

\begin{tabular}{|c|c|c|c|c|c|c|}
\hline \multirow{2}{*}{ Compound } & $\hat{C}_{v C O 2}$ & $\hat{C}_{v C O}$ & $\hat{C}_{v H 2 O}$ & $\hat{C}_{v H 2}$ & $\hat{C}_{v N 2}$ & $\hat{C}_{v O 2}$ \\
\cline { 2 - 7 } & $\mathrm{J} / \mathrm{mol}$ & $\mathrm{J} / \mathrm{mol}$ & $\mathrm{J} / \mathrm{mol}$ & $\mathrm{J} / \mathrm{mol}$ & $\mathrm{J} / \mathrm{mol}$ & $\mathrm{J} / \mathrm{mol}$ \\
\hline 1000 & 39.280 & 22.585 & 28.820 & 21.149 & 22.265 & 24.037 \\
\hline 1200 & 41.010 & 23.206 & 30.070 & 21.398 & 22.853 & 24.692 \\
\hline 1400 & 42.426 & 23.758 & 31.289 & 21.709 & 23.392 & 25.235 \\
\hline 1600 & 43.600 & 24.239 & 32.457 & 22.058 & 23.873 & 25.698 \\
\hline 1800 & 44.587 & 24.658 & 33.567 & 22.426 & 24.297 & 26.105 \\
\hline 2000 & 45.427 & 25.023 & 34.616 & 22.798 & 24.671 & 26.472 \\
\hline 2200 & 46.150 & 25.320 & 35.605 & 23.167 & 25.000 & 26.812 \\
\hline 2400 & 46.779 & 25.625 & 36.533 & 23.526 & 25.294 & 27.131 \\
\hline 2600 & 47.332 & 25.876 & 37.404 & 23.873 & 25.554 & 27.434 \\
\hline 2800 & 47.822 & 26.100 & 38.219 & 24.207 & 25.789 & 27.723 \\
\hline 3000 & 48.260 & 26.302 & 38.982 & 24.527 & 26.000 & 28.000 \\
\hline 3200 & 48.654 & 26.484 & 39.697 & 24.834 & 26.191 & 28.267 \\
\hline 3400 & 49.012 & 26.650 & 40.367 & 25.129 & 26.366 & 28.523 \\
\hline 3600 & 49.339 & 26.803 & 40.995 & 25.413 & 26.526 & 28.769 \\
\hline 3800 & 49.640 & 26.943 & 41.584 & 25.686 & 26.673 & 29.006 \\
\hline 4000 & 49.919 & 27.073 & 42.139 & 25.951 & 26.809 & 29.234 \\
\hline
\end{tabular}

Upon the average values of heat capacities, the combustion temperature may is calculated in iterative mode

$$
T=T_{0}+\frac{Q_{v}}{\sum_{i} y_{i} \cdot \hat{C_{v i}}}
$$

At temperatures attained by combustion of gaseous mixtures the heat capacities undergo of moderate alteration. By need of more precise evaluations average heat capacities quoted in Table 3 are to be interpolated. 


\section{Results and validation of calculation method}

The presented method of estimation of combustion parameters of fuel/air mixtures is illustrated by exemplary calculations carried out for two kinds of fuel/air mixtures. As a homogenous fuel the propane is considered. The results are compared with calculations performed by MWEQ thermodynamic code that assess presences of large number of chemical substances in combustion products [21].

\subsection{Evaluation of propane/air mixtures}

Obtained in calculations combustion pressure and temperature for various concentrations of propane are presented in Fig. 1. Stoichiometric concentration of propane (stech., 4,02\%) as well as low (LFL, 2,2\%) and upper (UFL, 9,5\%) flammability limits for propane/air mixtures are marked.

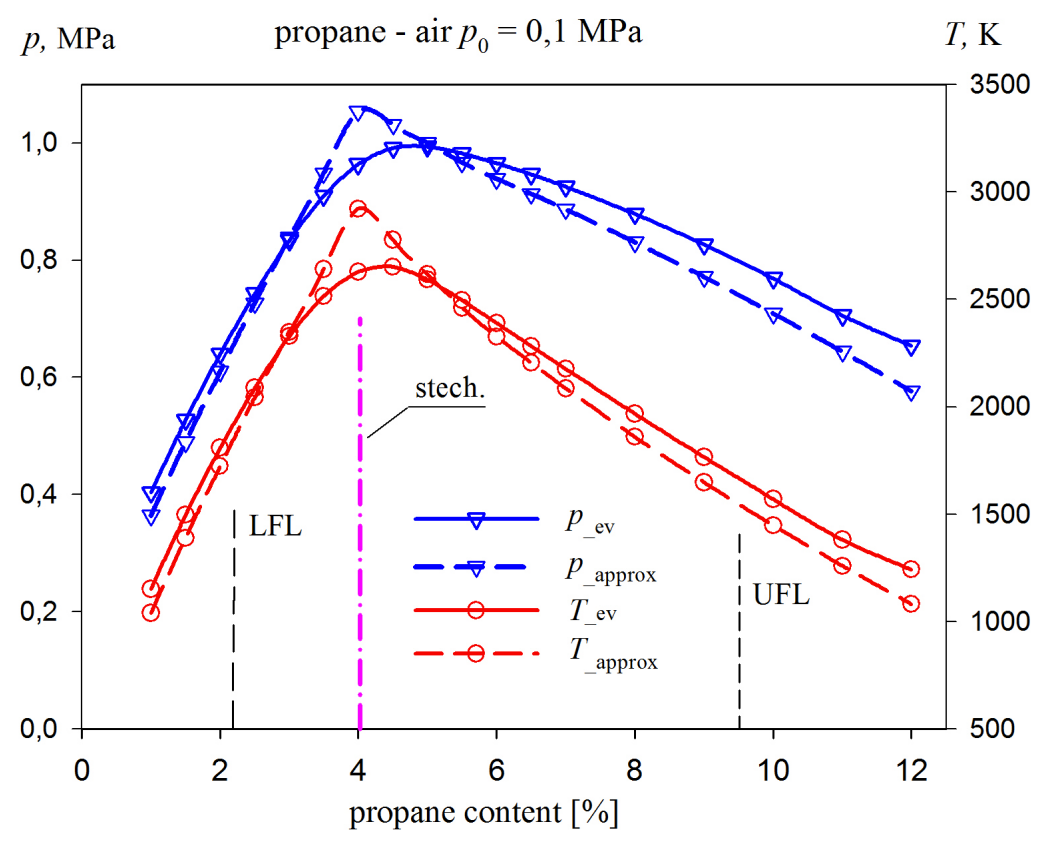

Figure 1. Pressure and temperature of propane/air combustion in closed space estimated by simplified approach (approx) and calculated by thermodynamic code (ev)

Detailed comparison of heat of combustion, temperature, pressure, and chemical composition obtained by use of simplified method presented in the paper with results of calculations performed by numerical program MWEQ [21] is set up in Table 4. Comparison was carried out for propane/air mixtures at propane content of $2,5 \%, 4 \%$ and $7 \%$ what correspond to lean, nearly stoichiometric, and fuel-rich mixtures.

The considerable differences between simplified method and results obtained in exact thermodynamic calculations occur near the stoichiometric point (4,021\% for propane). The differences are occurring due to excessive simplification of chemical composition of combustion products that is assumed by the simplified method. In simplified method formation of substances in maximal oxidation degree are assumed, i.e. of $\mathrm{CO}_{2}, \mathrm{H}_{2} \mathrm{O}$ and $\mathrm{N}_{2}$.

But the real equilibrium chemical composition is to meet thermodynamic principles of minimization of energy together with maximization of entropy [12]. Fulfilling thermodynamic requirements leads to appear in combustion products of non-fully oxidized substances ( $\mathrm{OH}, \mathrm{NO}$, etc.) as well as radicals $(\mathrm{H}, \mathrm{O}, \mathrm{N})$. The numerical package MWEQ [21] estimates the equilibrium state upon realization of the principle of minimization of thermodynamic potential of the reacting mixture.

As enthalpy of formation of non-fully oxidized products is positive their origination causes decrease in heat of combustion in comparison to values obtained by simplified method. The dependence of combustion heat upon concentration of propane is presented in Fig. 2.

Despite of differences in thermodynamic parameters (heat of combustion, temperature, and pressure) the resultant mole number obtained by simplified method and evaluated numerically are nearly same (Table 4, Fig.2). The total 
Table 4. Comparison of combustion parameters and chemical composition of combustion products for various concentrations of propane

\begin{tabular}{|c|c|c|c|c|c|c|}
\hline Parameter & \multicolumn{2}{|c|}{$c_{f}=2.5 \%$} & \multicolumn{2}{|c|}{$c_{f}=4.0 \%$} & \multicolumn{2}{|c|}{$c_{f}=7 \%$} \\
\hline$Q_{v}, M J / k g$ & 1.750 & 1.721 & 2.778 & 2.446 & 2.002 & 2.047 \\
\hline$p, \mathrm{MPa}$ & 0.726 & 0.743 & 1.054 & 0.9635 & 0.886 & 0.925 \\
\hline$T, \mathrm{~K}$ & 2042 & 2086 & 2920 & 2627 & 2085 & 2175 \\
\hline \multirow{2}{*}{ Species } & This paper & MWEQ & This paper & MWEQ & This paper & MWEQ \\
\hline & $\mathrm{mol} / \mathrm{kg}$ & $\mathrm{mol} / \mathrm{kg}$ & $\mathrm{mol} / \mathrm{kg}$ & $\mathrm{mol} / \mathrm{kg}$ & $\mathrm{mol} / \mathrm{kg}$ & $\mathrm{mol} / \mathrm{kg}$ \\
\hline $\mathrm{O}$ & & 0.0044 & & 0.0296 & & \\
\hline $\mathrm{O}_{2}$ & 2.712 & 2.6044 & 0.038 & 0.3405 & - & - \\
\hline $\mathrm{H}$ & \multirow{5}{*}{3.421} & 0.0003 & \multirow{5}{*}{5.431} & 0.0351 & \multirow{5}{*}{3.354} & 0.0220 \\
\hline $\mathrm{H}_{2}$ & & 0.0024 & & 0.1794 & & 4.5314 \\
\hline $\mathrm{OH}$ & & 0.0494 & & 0.2358 & & 0.0031 \\
\hline $\mathrm{H}_{2} \mathrm{O}$ & & 3.3938 & & 5.1164 & & \multirow[t]{2}{*}{4.8154} \\
\hline $\mathrm{HO}_{2}$ & & 0.0002 & & 0.0002 & & \\
\hline $\mathrm{N}_{2}$ & \multirow[t]{4}{*}{26.368} & 26.2703 & \multirow[t]{4}{*}{25.761} & 25.6577 & \multirow[t]{4}{*}{24.575} & 24.5743 \\
\hline $\mathrm{NO}$ & & 0.1958 & & 0.2067 & & 0.0003 \\
\hline $\mathrm{NO}_{2}$ & & \multirow[t]{2}{*}{0.0005} & & \multirow[t]{2}{*}{0.0001} & & \\
\hline $\mathrm{NH}_{3}$ & & & & & & 0.0002 \\
\hline $\mathrm{CO}$ & & 0.0091 & & 0.7627 & 7.020 & 5.8327 \\
\hline $\mathrm{CO}_{2}$ & 2.566 & 2.5569 & 4.074 & 3.3108 & & 1.1870 \\
\hline$\rho_{0}, k g / m^{3}$ & \multicolumn{2}{|c|}{1.220} & \multicolumn{2}{|c|}{1.230} & \multicolumn{2}{|c|}{1.249} \\
\hline$\sum y_{j}, \mathrm{~mol} / \mathrm{kg}$ & 35.67 & 35.087 & 35.304 & 35.875 & 40.954 & 40.967 \\
\hline
\end{tabular}

mole numbers obtained in numerical evaluation (solid line in Fig. 2) practically coincide with quantities obtained by simplified method (crosshairs, Fig. 2). The volume of gaseous products increases with raising fuel content. The initial mole number at $\mathrm{T}_{0}=288,15 \mathrm{~K}, \mathrm{p}_{0}=1$ bar is of $\mathrm{n}_{0}=41,7395 \mathrm{~mol} / \mathrm{m}^{3}$.

\subsection{Evaluation of multi-component fuel/air mixtures}

As the exemplary multi-component fuel, the composition containing of $55 \%$ of methane, $35 \%$ of ethylene and of $10 \%$ of benzene was considered.The mixture is based on methane, leading component of natural gas. As admixtures the exemplary olefin and aromatic hydrocarbon are added. Resulting parameters of the considered fuel are placed in Table 5.

Table 5. Initial data for $1 \mathrm{~mol}$ of the test-mixture $\mathrm{CH}_{4} / \mathrm{C}_{2} \mathrm{H}_{4} / \mathrm{C}_{6} \mathrm{H}_{6} 55 / 35 / 10$

\begin{tabular}{|c|c|c|c|c|c|}
\hline \multicolumn{2}{|c|}{ Chemical composition } & $\Delta_{f} H(298.15 K)$ & $Q^{t w}(298.15 K)$ & $n_{f}^{\text {stech }}$ & $\mu$ \\
\hline $\mathrm{C}$ & $\mathrm{H}$ & $\mathrm{kJ} / \mathrm{mol}$ & $\mathrm{kJ} / \mathrm{mol}$ & $\%$ & $\mathrm{~g} / \mathrm{mol}$ \\
\hline 1.85 & 4.2 & -14.40 & 11.67 & 6.74 & 26.4535 \\
\hline
\end{tabular}

Combustion heat, temperature, and pressure of combustion products of air mixtures of CH4/C2H4/C6H6 55/35/10 are presented in Fig. 3 


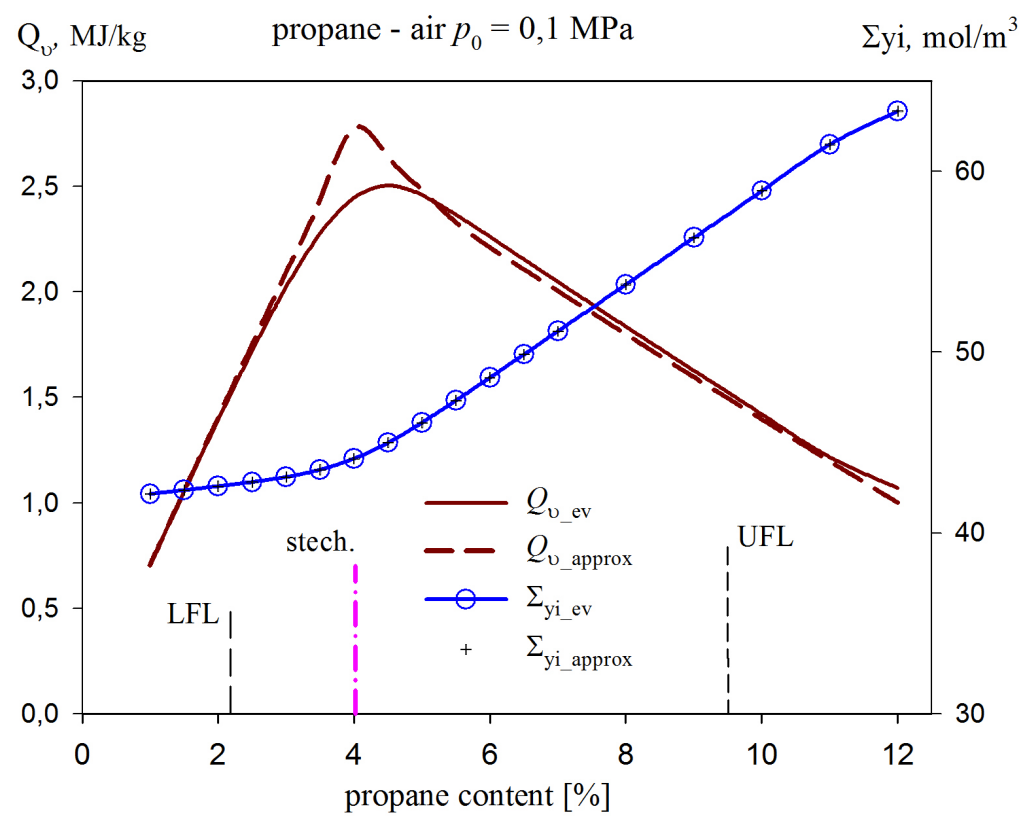

Figure 2. Heat of combustion $\left(\mathrm{Q}_{v}\right)$ and total mole number of gaseous products ( $\sum$ yi) of propane/air combustion in closed space estimated by simplified approach (approx) and calculated by thermodynamic code (ev)

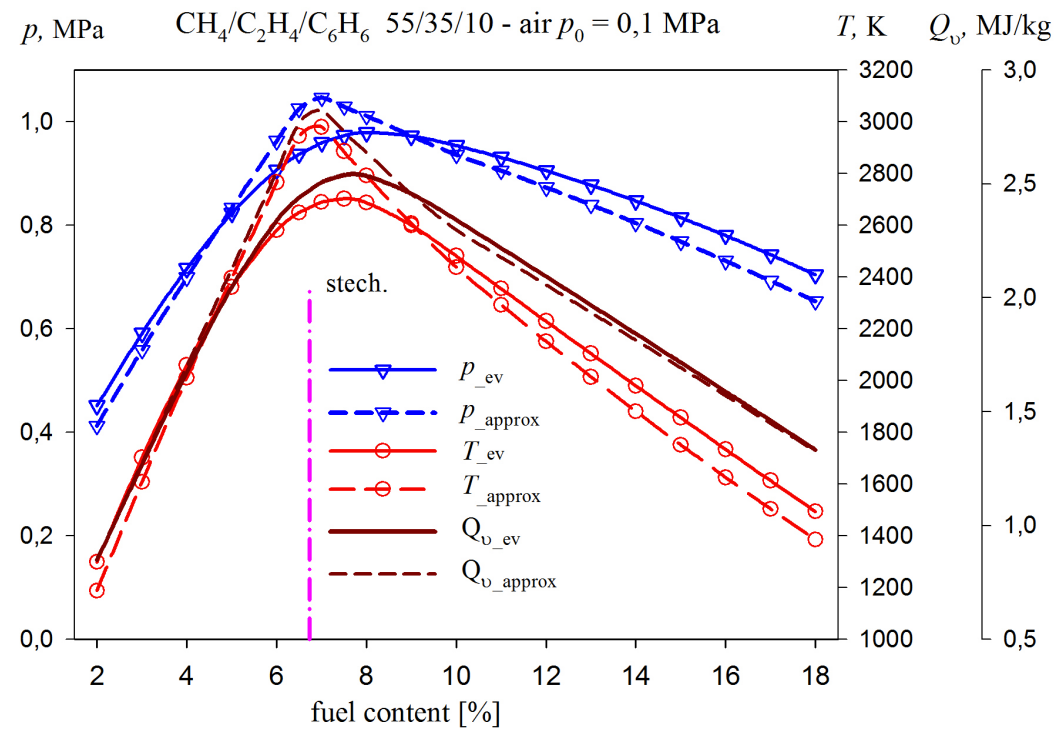

Figure 3. Pressure, temperature, and heat of closed space combustion of multi-component fuel mixtures $\mathrm{CH}_{4} / \mathrm{C}_{2} \mathrm{H}_{4} / \mathrm{C}_{6} \mathrm{H}_{6} 55 / 35 / 10$ with air

The obtained results confirm applicability of simplified method for estimation of combustion parameters in wide range of fuel concentrations. The results calculated for stoichiometric fuel concentrations are overestimated.

\section{Assessing of flammability limits}

The evaluated combustion parameters should cover the whole range of fuel concentration at which the considered mixture is able to undergo of combustion and explosion.

In the case of homogeneous fuels experimental data of low (LFL) and upper (UFL) flammability limits are mostly accessible. Flammability limits of several hydrocarbons are quoted in Table 6. 
Table 6. Flammability limits of hydrocarbons in gaseous phase [8]

\begin{tabular}{|c|c|c|c|}
\hline \multicolumn{2}{|c|}{ Compound } & LFL & UFL \\
\hline $\mathrm{CH}_{4}$ & methane & 5.30 & 15.00 \\
\hline $\mathrm{C}_{2} \mathrm{H}_{6}$ & ethane & 3.00 & 12.50 \\
\hline $\mathrm{C}_{3} \mathrm{H}_{8}$ & propane & 2.20 & 9.50 \\
\hline $\mathrm{C}_{4} \mathrm{H}_{10}$ & butane & 1.90 & 8.50 \\
\hline $\mathrm{C}_{5} \mathrm{H}_{12(g)}$ & pentane & 1.50 & 7.80 \\
\hline $\mathrm{C}_{6} \mathrm{H}_{14(g)}$ & hexane & 1.20 & 7.50 \\
\hline $\mathrm{C}_{7} \mathrm{H}_{16(g)}$ & heptane & 1.20 & 6.70 \\
\hline $\mathrm{C}_{8} \mathrm{H}_{18(g)}$ & octane & 1.00 & 6.70 \\
\hline $\mathrm{C}_{2} \mathrm{H}_{4}$ & ethylene & 3.10 & 32.00 \\
\hline $\mathrm{C}_{3} \mathrm{H}_{6}$ & propylene & 2.40 & 10.30 \\
\hline $\mathrm{C}_{4} \mathrm{H}_{8}$ & butene & 1.60 & 9.30 \\
\hline $\mathrm{C}_{3} \mathrm{H}_{6}$ & cyclopropane & 2.40 & 10.40 \\
\hline $\mathrm{C}_{6} \mathrm{H}_{6(g)}$ & benzene & 1.40 & 7.10 \\
\hline
\end{tabular}

Flammability of multi-component mixtures for which flammability limits of components are known may be evaluated upon the Le Chatelier's rule [18]

$$
F L_{m i x}=\frac{1}{\frac{x_{1}}{F L_{1}}+\frac{x_{2}}{F L_{2}}+\ldots+\frac{x_{n}}{F L_{n}}}
$$

where FL - flammability limit, low or upper; $\mathrm{x}_{i}$ - mole fraction of component "i".

In the case of considered mixture the employment of Le Chatelier's rule gives $\mathrm{LFL}_{C H 4 / C 2 H 4 / C 6 H 655 / 35 / 10}=3,43 \%$, $\mathrm{UFL}_{C H 4 / C 2 H 4 / C 6 H 655 / 35 / 10}=16,21 \%$.

When experimental data are not accessible, simplified methods of evaluation of flammability limits are to be used. One of simple and broadly used is the critical oxygen concentration method proposed by Jones [13]. Assuming general combustion reaction

$$
\mathrm{C}_{a} \mathrm{H}_{b} \mathrm{O}_{c}+x \cdot \mathrm{O}_{2} \Rightarrow a \mathrm{CO}_{2}+\frac{b}{2} \mathrm{H}_{2} \mathrm{O}
$$

flammability limits may be predicted as proportional to stoichiometric coefficient $C_{s t}$

$$
\begin{aligned}
& L F L=0.55 \cdot C_{s t} \\
& U F L=3.5 \cdot C_{s t}
\end{aligned}
$$

where

$$
C_{s t}=\frac{1}{1+\frac{x}{0.21}} \cdot 100 \%
$$

while 


$$
x=a+\frac{b}{4}-\frac{1}{2} c
$$

The calculations give reasonable agreement with experiments for low explosive limits but as a rule surpass the data for UFL [22]. For considered mixture we obtain $\mathrm{LFL}_{C H 4 / C 2 H 4 / C 6 H 655 / 35 / 10}=3,72 \%, \mathrm{UFL}_{C H 4 / C 2 H 4 / C 6 H 655 / 35 / 10}=$ $23,63 \%$.

The wide and exhaustive analysis of both experimental methods and theoretical formulae for estimation of flammability limits is given by Grabarczyk et. al. [11]. The performed investigations indicate difficulties in proper prediction of upper flammability concentrations. The oxygen deficiency increases complexity of chemical reactions occurring by decomposition and combustion of fuel-rich media.

On the other hand, Grabarczyk et. al. [11] indicates that low flammability limits build a measurable key tool in evaluation of explosion viability and critical safety parameters.

\section{Conclusions}

In the paper a simplified method of estimation of maximal parameters of combustion of gaseous mixtures in closed space is presented. The introductory step of the method is estimation of simplified chemical composition of combustion products. The decomposition rules for mixtures of positive, negative, and highly negative oxygen balance are given.

The method enables of estimation of maximal combustion heat, temperature, and pressure of combustion and explosion of gaseous mixtures in closed spaces. Exemplary calculations are carried up for gaseous hydrocarbon/air mixtures. Obtained results are compared with extended numerical calculations preformed by program that include large number of components present in combustion products. Well agreement is attained at wide concentration of fuel. Full flammability region is covered.

The method is intended to serve as quantitative tool by assessing of combustion and explosion hazard imposed by combustible gaseous mixtures.

\section{References}

1. Baker, W., Cox, P., Westine, P., Kulesz, J. \& Strehlow, R. Explosion Hazards and Evaluation (Elsevier, Amsterdam, 1983).

2. Baryłka, A. Zagadnienie zdatności obiektów budowlanych do użytkowania w problematyce inżynierii bezpieczeństwa tych obiektów. Inżynieria Bezpieczeństwa Obiektów Antropogenicznych 4 (2019).

3. Baryłka, A. The impact of fire on changing the strength of the underground shelter structure. Rynek Energii 146, 71-75 (2020).

4. Bowen, P. \& Cameron, L. Hydrocarbon aerosol explosion hazards. Trans IChemE 77, 22-30 (1999).

5. Chase, M. e. a. NIST-JANAF Thermochemical Tables, Monograph. Journal of Physical and Chemical Reference Data 9 (1998).

6. Chyży, T. \& Mackiewicz, M. Simplified function of indoor gas explosion in residential buildings. Fire Safety Journal 87, 1-9 (2017).

7. Ciccarelli, G. \& Dorofeev, S. Flame acceleration and transition to detonation in ducts. Progress in Energy and Combustion Science 34, 499-550 (2008).

8. Crowl, D. Understanding Explosions (American Institute of Chemical Enginers, New York, 2003).

9. Czyż, M. \& Grzebielec, A. Modification of the cascade methane liquefaction process to improve the efficiency of the system. Inżynieria Bezpieczeństwa Obiektów Antropogenicznych 2, 43,48 (2021).

10. Glushko, V. e. a. Termodinamicheskije Svoistva Individualnykh Veshchestv (Nauka, Moscow, I-IV, 1978-1982).

11. Grabarczyk, M., Ciesińska, W. \& Porowski, R. Lower Flammability Limits - Experimental and Theoretical Determination Methods for Gaseous and Liquid Fuels. State of the Art. Problems of Mechatronics, Armament, Aviation, Safety Engineering 7, 85-114 (4 2016).

12. Gumiński, K. Chemia Fizyczna (Państwowe Wydawnictwo Naukowe, Warszawa, 1980).

13. Jones, G. Inflammation limits and their practical application in hazardous industrial operations. Chem. Rev 22, $1-26$ (1938).

14. Kamlet, M. \& Jacobs, S. Chemistry of Detonations. I. A Simple Method for Calculating Detonation Properties of C-H-N-O Explosives. J. Chem. Phys 48, 23-35 (1968). 
15. Keshavarz, M., Kamalvand, M., Jafari, M. \& Zamani, A. An Improved Simple Method for the Calculation of the Detonation Performance of CHNOFCl, Aluminized and Ammonium Nitrate Explosives. Central European Journal of Energetic Materials 13, 381-396. https://www.wydawnictwa.ipo.waw.pl/cejem (2 2016).

16. Klapotke, T. Chemistry of High-Energy Materials (De Gruyter, Berlin, 2015).

17. Kowalewicz, A. Podstawy Procesów Spalania (Wydawnictwa Naukowo-Techniczne, Warszawa, 2000).

18. LeChatelier, H. Estimation of firedamp by flammability limits. Ann. des mines. 8e XIX, 388-395 (1891).

19. Mallard, E. \& LeChatelier, H. Recherches expérimentales et théoriques sur la combustion des mélanges gazeoux explosifs. Ann. des mines. 8e 4, 274-388 (1883).

20. Orlenko, L. e. a. Fizika Vzryva (Fizmatlit, Moskwa, 2004).

21. Papliński, A. Implementation of the Steepest Descent Method to Evaluation of Equilibrium Composition of Reactive Mixtures Containing Components in Condensed Phases. Central European Journal of Energetic Materials 4, 135-150 (1-2 2007).

22. Papliński, A. Wybuchy gazu w pomieszczeniach zamkniętych - rozpoznanie charakterystyk i przeciwdziałanie zagrożeniom. Inżynieria Bezpieczeństwa Obiektów Antropogenicznych 5, 9-14. https: //www . inzynieriabezpieczenstwa . com.pl (3 2016).

23. Weast, R., Lide, D., Astle, M. \& Beyer, W. CRC Handbook of Chemistry and Physics (CRC Press, Boca Raton, 1990). 